\title{
POLA PENATAAN RUANG RUMAH COMPOUND DI KAWASAN KOTA GEDE DALAM PERSPEKTIF GENDER
}

\author{
Cerrya Wuri Waheni* \\ Program Pascasarjana Institut Seni Indonesia Yogyakarta
}

\begin{abstract}
ABSTRAK
Pemahaman peranan gender hampir tidak pernah dilakukan dalam pembahasan ilmu desain interior. Dengan perkembangan ilmu desain interior yang muncul akibat gagalnya modernisme yang dipicu oleh gerakan feminisme, mengakibatkan perhatian terhadap peranan gender muncul ke permukaan. Peranan gender dalam kajian ini difokuskan kepada peranan laki-laki maupun perempuan dalam perkembangan pola penataan ruang rumah tradisional Jawa, dengan mengambil kasus pola penataan ruang rumah compound di wilayah Kotagede dan mencoba melihat pola penataan ruang yang mengikuti tradisi dan pola penataan yang mengikuti jaman sekarang, untuk melihat sejauh mana perubahan peranan gender dalam tempat dan kurun waktu tertentu.

Melalui kajian ini ditemukan bahwa peranan gender dalam pola penataan ruang rumah compound di wilayah Kotagede tidak banyak berubah, kecuali beberapa peralihan fungsi dan peran dari masing-masing gender. Ditemukan keunikan dalam rumah compound di kawasan Kotagede saat ini, yaitu setiap rumah yang ada memiliki bagian inti rumah tradisional Jawa yaitu terdapat plinggitan, dalem dan sentong. Pola penataan ruang rumah compound saat ini tidak ada batasan antara laki-laki dan perempuan. Artinya, laki-laki dan perempuan boleh menggunakan ruangan manapun, dan perbedaan pola penataan ruang tergantung pengguna dan penggunaannya pada kegiatan rutin atau non-rutin/adat yang berlangsung.
\end{abstract}

Kata Kunci: gender, pola penataan ruang, rumah compound.

\section{PENDAHULUAN}

Berbicara tentang ruang erat kaitannya dengan arsitekturalnya. Konteks ruang disini berkaitan dengan rumah. Rumah merupakan salah satu wujud kedudukan sosial. Pemahaman tentang rumah sama dengan pemahaman mengenai kehidupan suatu kelompok kebudayaan yang memunculkan suatu kekhasan yang direpresentasikan melalui ruang untuk berpenghuni. Rumah dalam kaitan ini merupakan suatu konsep dalam mengaktualisasi diri baik pribadi maupun sosial. Makna rumah lebih dari sekedar struktur bangunan fisik namun satuan simbolis dan sosial. Ruangruang tersebut menampung struktur sosial yang berkaitan dengan peran para penghuninya, meliputi suami, istri, anak-anak serta anggota keluarga lainnya dalam lingkup keluarga.

Dalam Kebudayaan Jawa memiliki sistem kekerabatan yang unik, yang memperlihatkan kedudukan dan peran seseorang di dalam kehidupan berkeluarga dan bermasyarakat. Dalam pandangan masyarakat Jawa, keseimbangan antara hak dan kewajiban selalu berlangsung dalam ruang, waktu, makna dan pesan, termasuk didalamnya memperlihatkan sistem kekerabatan antara pria dan wanita. (Nugroho, 2008)

Batasan relasi gender memperlihatkan bahwa kedudukan dan peran pria lebih dominan dibanding dengan wanita. Implikasi secara umum adalah wanita menjadi sub-ordinat pria. Wanita Jawa diharapkan dapat menjadi pribadi yang selalu tunduk dan patuh pada hegemoni kekuasaan seorang pria, yang pada masa dulu terlihat dalam sistem kekuasaan kerajaan Jawa (kraton). Pandangan hidup ini secara jelas terstruktur dalam rumah tinggalnya.

Secara historis, relasi gender dalam masyarakat Jawa juga terepresentasikan melalui ruang arsitektur, dalam hal ini diperlihatkan dalam konsep tata ruang rumah tradisional Jawa pada masa dahulu dimana konsep dan pola penataan ruang sangat terkait dengan pembatasan gender. Implikasi lebih luas dapat dipahami dari pemisahan kegiatan sosial dan ritual bagi pria dan wanita. Dari penataan ruang yang dihadirkan dalam sebuah rumah tinggal akan diketahui peranan antara pria dan wanita dalam struktur sosial keluarga. Pria berperan dalam melindungi dan mewakili. Pria berhak duduk di ruang tamu sebagai perwakilan dari keluarga. Ruang dalam menjadi milik wanita, seperti 
halnya dapur sebagai area dominan wanita. Sehingga pola ruang terdapat perbedaan antara ruangruang bagi pria dan ruang-ruang bagi wanita.

Rapoport dalam bukunya House, Form, and Culture menyatakan bahwa arsitektur sebagai tanda (mark) dari suatu lingkungan binaan (built environment), atau juga sebagai tanda adanya sebuah kebudayaan (culture). Dalam tulisannya wanita tidak berperan dalam berarsitektur. Namun, wanita cenderung berperan sebagai pengguna (user) karya arsitektur, yang pada umumnya dibuat oleh pria. Dengan demikian, menurut Rapoport, adanya keseimbangan peran sosial pria dan wanita dalam masyarakat vernakuler sudah menjadi budaya.

Struktur rumah akan merepresentasikan pandangan dan tujuan hidup serta nilai-nilai dan hubungan di antara mereka yang tinggal di dalamnya. Segala aktivitas dan interaksi pada rumah tinggal tertuang dalam ruang-ruang. Pemahaman penghuni terhadap makna yang terbentuk di dalam rumah akan terwujud sebagai susunan ruang dan tercermin dalam perilaku keseharian dengan mengekspresikan pemahaman terhadap rumah melalui penyusunan objek maupun penempatan pola dalam ruang, sehingga tidak menutup kemungkinan peran sesuai gender juga berpengaruh di dalamnya, yang dijadikan dasar dalam mewujudkan arsitektur dan interior rumah tinggalnya.

Kotagede, merupakan salah satu kawasan pewaris tradisi Kerajaan Mataram Islam. Oleh karena itu Kotagede dibentuk secara tipologis dan morfologis kraton (Ronald, 1998). Soeryanto dan Indanoe (1987) dalam Iswati (2001: 28) menyebutkan ada lima tipe pemukiman di Kawasan Kotagede, salah satunya yaitu pola dengan tatanan dari beberapa kelompok hunian dan dihubungkan oleh jalan rukunan, pola kluster dari beberapa unit hunian yang terbentuk dalam satu lingkungan yang dibatasi oleh dinding, pola dengan beberapa hunian dengan tipe individual dan membentuk suatu pola kolektif, pola kluster dalam satu lingkungan berpagar dinding dengan jalan rukunan di depan pendapa, dan pola kluster berpagar dinding dengan akses hanya dari samping. Ciri pemukiman warga tersebut disebut sebagai omah compound.

Objek penelitian dan kajian yang akan penulis teliti yaitu, pola penataan ruang rumah compound di kawasan KG dalam perspektif gender. Bagaimanakah peranan gender dalam penataan ruang rumah compound tersebut dalam keseharian, adakah pola ruang di dalam rumah terpengaruh pada peranan gender, karena masyarakat Jawa dalam kehidupannya memiliki aturan-aturan yang telah dikonstruksi oleh sosial sejak zaman dahulu, baik itu hidup di luar rumah, maupun berada di dalam rumah. Apakah dalam rumah compound aturan tersebut masih berlaku? Inilah hal menarik yang ingin penulis ketahui, bagaimana fungsi rumah tersebut pada masa sekarang ini.

Seiring perkembangan zaman, tentu saja tidak menutup kemungkinan akan banyak terjadi perubahan. Seperti kemajuan di bidang teknologi, perkembangan ekonomi, politik, migrasi penduduk, serta faktor-faktor lain banyak mengubah situasi pola hidup masyarakat. Persoalan yang menarik ialah, ketika artefak peninggalan budaya berdinamika dengan perkembangan masyarakat. Tentu saja akan terjadi berbagai kegiatan manusia yang saling berkaitan dalam satu sistem kegiatan. Demikian juga wadah-wadah berbagai kegiatan atau ruang-ruang (space) tersebut, yang juga terkait dalam satu sistem, yang disebut dengan 'sistem ruang'. Keterkaitan ruang-ruang sebagai wadah kegiatan inilah yang membentuk 'tata ruang' atau 'pola ruang' yang tertuang sebagai bagian dari arsitektur (Haryadi \& B. Setiawan, 1995: 31).

Pola dan tatanan yang dimunculkan pada rumah compound ini memiliki keunikan dan karakteristik yang dirasakan, serta mengandung nilai-nilai filosofi yang mendalam. Melalui penelitian ini penggagasnya seakan ingin menyampaikan pesan-pesan moral bagi generasi terutama lingkungan sekitar. Kawasan Kotagede, sebagai bagian dari suatu era, kawasan ini secara langsung maupun tidak langsung juga akan terpengaruh oleh modernitas. Sehingga terjadi penyesuaianpenyesuaian terhadap nilai budaya kesehariannya termasuk didalamnya tentang pola dan pemanfaatan ruang pada rumah tinggalnya. Oleh karena itu, perlu kiranya dikaji lebih lanjut mengenai peranan gender sekaligus yang terefleksikan di balik pola rumah compound yang ada di kawasan Kotagede.

\section{METODE}

Metode yang digunakan pada penelitian ini adalah metode kualitatif. Dalam penelitian kualitatif sampel penelitian mencakup dua aspek yaitu informan dan situasi sosial. Informan merupakan subyek yang benar-benar mengetahui informasi yang dibutuhkan. Sementara situasi sosial merupakan subyek yang akan diamati, dalam hal ini bisa berupa tempat, lingkungan sosial, organisasi dan sebagainya (Sanapiah, 1990:56-61). 
Penelitian ini mengurai berbagai fakta dan nilai budaya yang terdapat dari lingkup objek penelitan untuk menghasilkan pemaknaan atas pola rumah coumpound di kawasan $\mathrm{KG}$ dalam perspektif gender. Melalui metode penelitian ini akan dilakukan proses penyusunan, pengkategorian, pencarian makna atau pula dengan tujuan memahami persoalan gender.

Beberapa variabel yang menentukan analisis data ialah pola huni dan aktivitas hidup penghuni rumah compound sehari-hari. Penelitian akan berupaya untuk mendeskripsikan proses peran dan kedudukan gender yang terepresentasikan dalam visualisasi ruang dan pembagian ruang.

\section{Teknik Pengumpulan Data}

Pengumpulan data dalam penelitian ini dilakukan melalui lima cara, yaitu: Penetapan populasi dan sampel, Studi pustaka, Observasi, Wawancara dan Dokumentasi. Studi pustaka dilakukan sebelum dan sesudah observasi dan wawancara.

\section{Teknik Analisis Data}

Tahapan analisis data adalah bagian terpenting dari seluruh pekerjaan penelitian, karena tujuan analisis data ialah untuk menyederhanakan hasil penelitian, sehingga hasil kajian mudah di tafsirkan.

Untuk menyederhanakan tahap analisis data, penelitian ini akan membagi beberapa sub bagian yang terpenting yang akan dilakukan saat melakukan analisis, meskipun data tidak harus selalu dikumpulkan: sering bisa digunakan bahan yang sudah ada (Ibrahim, 2009:6). Bahan yang sudah ada yang bisa dijadikan pekerjaan utama untuk dianalisis ialah:

1. Dokumentasi foto rumah compound yang sudah diobservasi, tahap utama yang dilakukan yaitu, membagi bagian rumah yang terdapat di dalam foto/video.

2. Menulis segala kalimat yang disampaikan oleh narasumber yang ada di dalam dokumentasi.

3. Menyusun kalimat narasumber menjadi kalimat baku, yang ada, baik itu, tersirat maupun yang tersurat.

4. Menyusun draf yang akan dijadikan tulisan.

5. Menyusun tanda yang terdapat dalam pola penataan ruang rumah compound, untuk dialakukan analisis lebih dalam.

6. Melakukan analisis terhadap data yang sudah di kumpulkan dengan menggunakan teori.

Analisis data ini dilakukan untuk mencari tahu jawaban dari permasalahan yang ada. Adapun parameter yang digunakan ialah dengan melakukan studi pustaka dan melakukan observasi lapangan serta melakukan wawancara langsung yang berkaitan dengan pola rumah compound di kawasan KG.

\section{PEMBAHASAN}

Pola pemukiman compound terbentuk dari kelompok rumah dan ruang terbuka yang memanjang. Keberadaan pola pemukiman compound di Kotagede tidak terlepas dari adanya jalan rukunan sebagai area sirkulasi warga. Menurut Indanoe dalam Indratoro (1995:28) ada 3 pola pemukiman compound di Kotagede antara lain:

a. Pola compound dengan dua/lebih deretan rumah ke arah timur-barat dengan jalan setapak yang terletak diantara pendapa dan dalem, jalan setapak ini dihubungkan oleh jalan setapak (arah utara selatan dengan deretan rumah sekelilingnya.

b. Pola compound dengan dua atau lebih deretan rumah ke arah timur-barat dengan jalan setapak yang terletak diantara bangunan pandapa dan dalem (tanpa ada jalur penghubung dengan deretan rumah sebelahnya).

c. Pola compound dengan dua/lebih deretan rumah kearah timur-barat dengan jalan setapak di depan bangunan pendapa. 


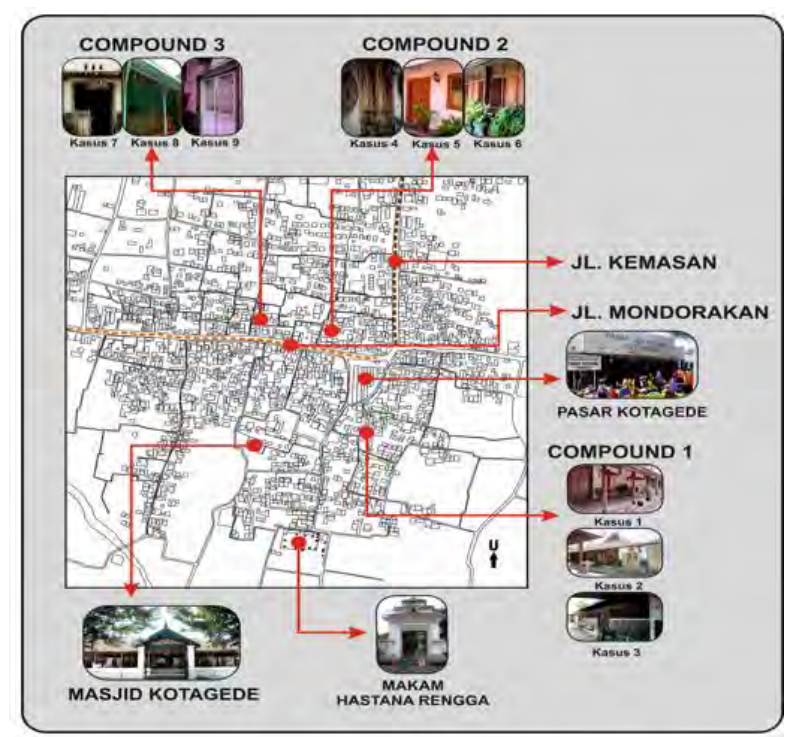

Gambar 1 Lokasi penelitian (Sumber: Cerrya Wuri, 2017)

Menurut hasil penelitian Ikaputra (1993) dalam Iswati (2001:37) diperoleh temuan bahwa rumah tinggal yang terdapat di Kotagede selalu memiliki bagian inti (yaitu bagian yang selalu ada, ditemukan pada $80 \%$ lebih dari sampel) yang terdiri dari ruang tamu, ruang tidur dan dapur. Menurut hasil penelitian Islam (2000) dalam Iswati (2001:37) diperoleh temuan bahwa pada rumah tinggal di lahan terbatas selalu diprioritaskan adanya $\mathrm{KM} / \mathrm{WC}$ dan ruang tidur, kemudian prioritas kedua adalah ruang tamu.

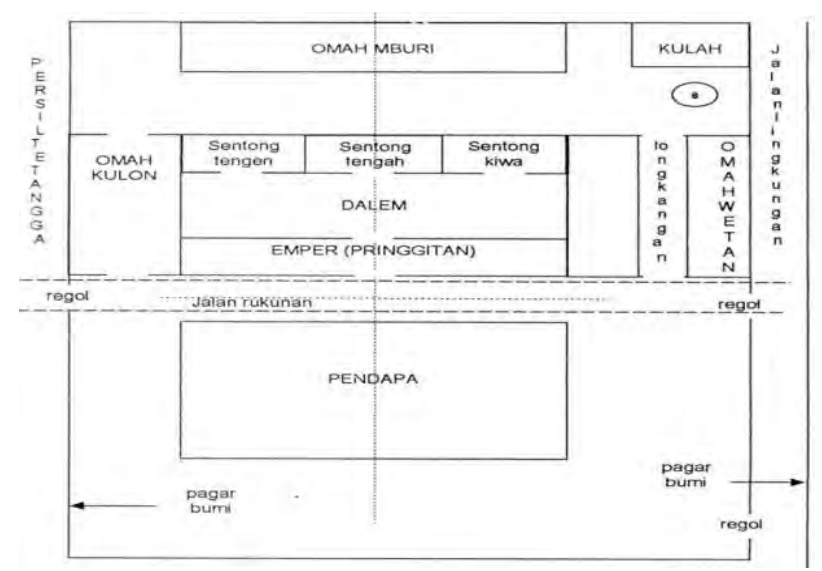

Gambar 2 Rumah tipe lengkap Kotagede. (Sumber: Iswati, 2001)

Aktivitas yang berlangsung di dalam rumah akan di analisis menggunakan teori Rapoport yang terbagi menjadi aktivitas rutin/basic needs (kegiatan sehari-hari) atau non-rutin (kegiatan ritual), Familiy, Position of women, Privacy, and Social intercourse.Dalam menganalisa pola penataan ruang rumah tinggal compound di KG dalam persepektif gender, analisa dari kelima hal tersebut sepenuhnya terlihat dari pemetaan aktivitas dan teritorial gender laki-laki dan perempuan didalam penggunaan ruang-ruang dan waktu, meliputi penggunaan ruang-ruang yang ada sehariharinya termasuk pada hari-hari tertentu apabila ada kegiatan adat.

Pola penataan ruang dan pemetaan aktivitas terhadap ruang-ruang terdiri dari:

a. Emper: difungsikan sebagai ruang duduk sebagai ruang tamu, dan ruang keluarga.

b. Dalem: difungsikan sebagai ruang tidur dan area simpan pakaian.

c. Sentong: difungsikan sebagai ruang ibadah, sentong kiwo sebagai tempat simpan pakaian dan sentong kiwo/timur sebagai ruang tidur.

d. Gandok Tengen/Barat: terbagi menjadi 3 bagian yaitu, 2 buah kamar tidir dan ruang makan.

e. Gandok Belakang: difungsikan sebagai ruang simpan perkakas/gudang. 
f. Longkangan: difungsikan sebagai dapur dengan aktivitas memasak didalamnya.

g. Jalan Rukunan: difungsikan sebagai area sirkulasi warga lingkungan sekitar. Aktivitas yang terjadi pada jalan rukunan ini biasanya sebagai ruang interaksi antar tetangga dan sesekali waktu sebagai ruang untuk acara warga, misal tirakatan dan hajatan.

Aktivitas yang berlangsung di dalam rumah terdiri dari aktivitas rutin/basic needs dan nonrutin/kegiatan ritual. Pembatasan ruang secara fisik untuk kegiatan laki-laki dan perempuan pada ruang rumah tidak ditemui. Artinya laki-laki maupun perempuan dapat menggunakan ruang yang sama dan kapasitas yang sama.Melihat pemetaan aktivitas dan teritorial gender laki-laki dan perempuan di dalam menggunakan ruang-ruang yang ada sehari-harinya termasuk pada hari-hari tertentu apabila ada kegiatan adat di kawasan rumah compund KG adalah sama, antara laki-laki dan perempuan boleh menggunakan ruangan manapun. Uniknya, di kawasan KG pola penataan ruang mayoritas sama masih berdasarkan kaidah tradisional Jawa. Artinya, masih ditemui dalam rumah tinggal tersebut terdapat plinggitan, dalem dan sentong atau bagian inti dalam rumah tradisional Jawa.

Saat ini, fungsi dan bentuk atau pola penataan ruang merupakan tema utama didalam pembentukan suatu bangunan. Hubungan fungsi dan pola penataan ruang banyak memperoleh perhatian dari para pakar, salah satunya Socrates yang menyatakan bahwa bentuk yang baik dalam pengertian absolute jika terkait dengan fungsi. Hubungan antara fungsi dan bentuk sangat dipengaruhi juga oleh beberapa faktor, dalam hal ini salah satu faktor yang sangat berpengaruh dalam kehidupan masyarakat adalah gender. Pembentukan dan penataan ruang berdasarkan gender dapat dipakai untuk menilai tingkat privasi ruang berdasarkan jenis kegiatan yang terjadi di dalamnya.

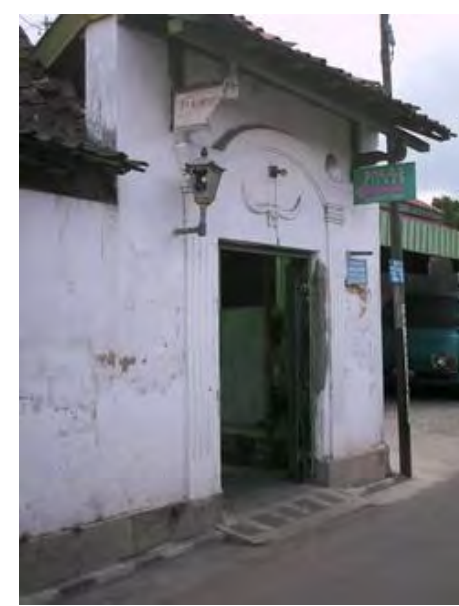

Gambar 3 Pintu Masuk

Compound"Between Two Gates".

(Sumber: Cerrya Wuri, 2017)

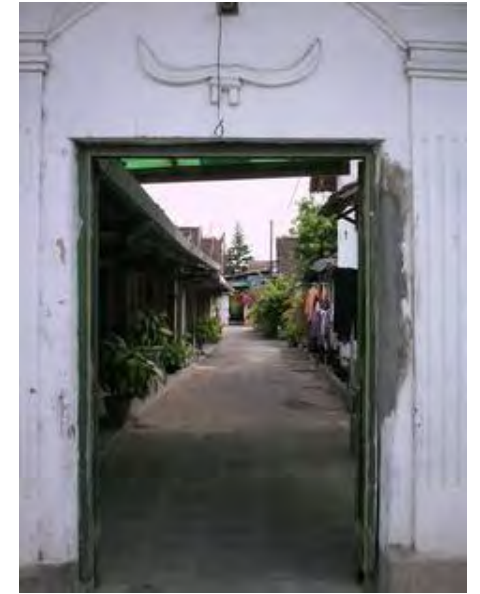

Gambar 4 Jalan Rukunan dalam "Compound Between Two Gates"

(Sumber: Cerrya Wuri, 2017)

Akibat pola penataan ruang berdasarkan gender ini secara langsung akan berpengaruh pada fungsi ruang tersebut, diantaranya:

a. Bapak : dominan berada di emper sebagai ruang keluarga pada malam hari, dan berada digandok tengen/barat sebagai ruang tidur utama, selain itu di sentong kiwo sesekali waktu untuk beribadah/sholat ketika dirumah.

b. Ibu : dominan menghabiskan waktu longkangan/dapur terutama pagi hari, di gandok tengen/barat sebagai ruang tidur utama dan di emper sebagai ruang keluarga pada saat malam hari, jalan rukunan di sore hari.

c. Anak : dominan berada di emper sebagai ruang keluarga untuk bersantai dan sesekali menonton $\mathrm{TV}$, dan sentong kiwosebagai ruang tidur anak.

Sedangkan pengaruh gender terhadap ruang-ruang yang ada, diantaranya Pengaruh sifat kelelakian dan keperempuanan yang mempengaruhi pembentukan ruang tidak berpengaruh pada beberapa ruang, peranan gender tersebut secara umum tidak dipahami oleh pemiliknya. Ruang yang cukup kuat dipengaruhi oleh gender perempuan yaitu longkangan/dapur untuk memasak dan 
menyiapkan matengen. Sedangkan peranan gender laki-laki tidak begitu kuat tampak pada rumah tinggal ini.

Dalam mempersoalkan gender terhadap pola penataan ruang terkesan bahwa di dalam dunia konseptualnya tidak tersimpan visi yang dominan. Dalam konteks kehidupannya saat ini, aspek gender tetap akan menjadi suatu faktor di dalam penataan suatu ruang dan bangunan, hal ini menandakan bahwa saat ini gender sudah mulai menjadi suatu pertimbangan di dalam penataan suatu ruang.

Ada perbedaan pengguna dan penggunaannya pada kegiatan rutin/basic need dan kegiatan adat yang berlangsung. Ruang yang mempunyai sifat privat, bisa berubah menjadi semi privat atau ruang yang semula semi publik berubah menjadi publik. Perubahan sifat ruang merubah tingkat privasi ruang yang semula hanya diperuntukkan atau dipergunakan anggota keluarga saja, berubah menjadi rendah dengan penggunaan orang lain. Hal ini terjadi pula terhadap ruang yang hanya diperuntukkan bagi laki-laki, namun dipergunakan oleh anggota keluarga perempuan. Hal tersebut disebabkan oleh pola hubungan sosial dan kebutuhan.

Pada penataan ruang saat ini banyak sekali perubahan secara fungsi terutama perubahan yang disebabkan oleh pengaruh gender. Sebagai contoh ruang tamu yang terletak di depan memiliki fungsi sosial bagi laki-laki dan perempuan (ruang publik), sementara dapur sebagai ruang privat bagi perempuan. Jadi, pembagian ruang publik dan ruang privat tidak mesti yang di depan yang berfungsi sebagai ruang publik dan semakin ke belakang bersifat privat. Penggunaan ruang publik tidak mutlak untuk laki-laki saja melainkan untuk perempuan juga.

Berdasarkan dari pengamatan yang di dapat hampir semua rumah compound yang ada di kawasan KG saat ini hampir memiliki kesamaan yang unik, baik dari pola penataan ruang dan bentuk rumahnya. Setiap anggota rumah compound yang ada pastiterdiri dari plinggitan, dalem dan sentong atau bagian inti dalam rumah tradisional Jawa.

Pembatasan ruang secara fisik untuk kegiatan laki-laki dan perempuan pada ruang rumah tidak ditemui. Artinya laki-laki maupun perempuan dapat menggunakan ruang yang sama dan kapasitas yang sama. Disamping itu terlihat adanya kecenderungan hubungan antara laki-laki dan perempuan melalui pembagian peran. Antara laki-laki dan perempuan, masing-masing ingin mengaktualkan dirinya dengan kompromi terhadap lainnya sesuai dengan kesepakatan yang telah disetujui, jadi secara umum tidak terjadi diskriminasi perempuan dalam penataan setiap ruang atau perwujudan bentuk ruang.

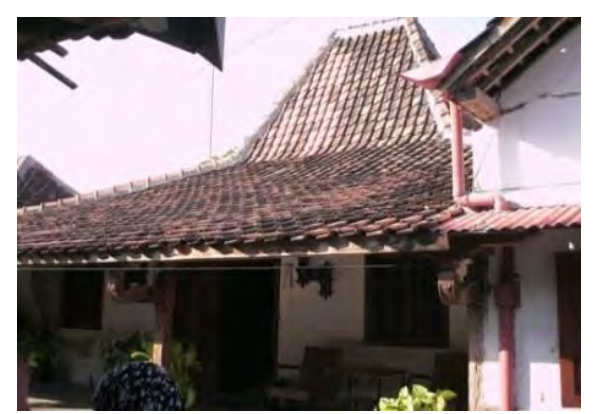

Gambar 5 Tampak depan rumah tinggal, terdapat teras sebagai area santai dan sesekali menerima tamu, dominan oleh gender lakilaki. (Sumber : Cerrya Wuri, 2017)

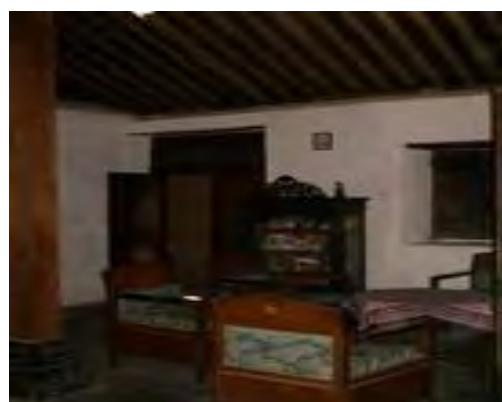

Gambar 6 nDalem, difungsikan sebagai ruang keluarga, seimbang antara gender lakilaki dan perempuan.

(Sumber: Cerrya Wuri, 2017) 


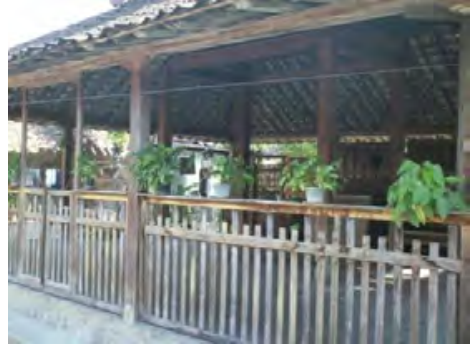

Gambar 7 Pendopo yang terpisah oleh jalan rukunan dengan rumah induk digunakan sebagai ruang tamu pada acara-acara tertentu, dominan gender laki-laki.

(Sumber : Cerrya Wuri, 2017)

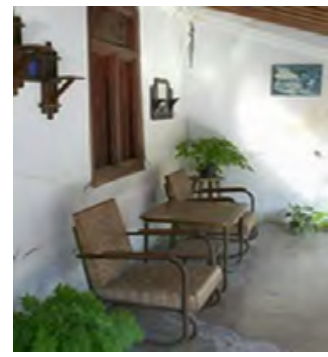

Gambar 9 Teras rumah sebagai area duduk, santai pada sore hari dan menerima tamu, dominan oleh gender laki-laki. (Sumber : Cerrya Wuri, 2017)

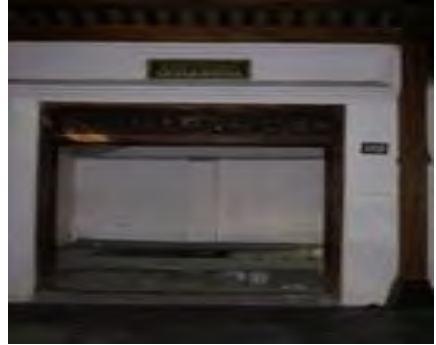

Gambar 8 Sentong tengah, difungsikan sebagai ruang ibadah, seimbang antaragender laki-laki dan perempuan

(Sumber : Cerrya Wuri, 2017)

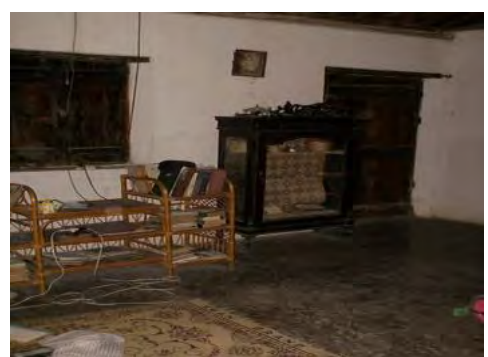

Gambar 10 Ruang koleksi pada dalem / ruang keluarga, seimbang antara gender lakilaki dan perempuan.

(Sumber: Cerrya Wuri, 2017)

\section{KESIMPULAN}

Berdasarkan hasil penelitian yang di dapatkan pada pembahasan tentang pola penataan ruang rumah compound dalam perspektif gender di kawasan $\mathrm{KG}$, diantaranya bahwa pengaruh gender di dalam pola penataan ruang telah mengalami perubahan makna dibandingkan pada rumah compound tradisional. Pada rumah compound tradisional pembagian ruang antara laki-laki dan perempuan sangat jelas sekali karena dibatasi oleh pengaruh-pengaruh adat istiadat yang sangat tabu untuk dilanggar masing-masing gender. Pada zaman dahulu pembagian ruang berdasarkan gender dapat dipakai untuk menilai tingkat privasi ruang berdasarkan kegiatan yang terjadi di dalamnya.

Namun saat ini, makna lama tersebut hampir tidak di temukan, hal ini didasarkan oleh pengaruh keyakinan beragama yang lebih dominan di bandingkan pengaruh dan batasan yang ditimbulkan oleh adat istiadat kelompok masyarakat tersebut. Sekarang ini, perbedaan pola penataan ruang tergantung pengguna dan penggunaannya pada kegiatan rutin atau non-rutin/adat yang berlangsung. Peranan gender tidaklah selalu mempengaruhi pada pola penataan ruang di dalam rumah compound. Pola penataan ruang rumah compound saat ini tidak ada batasan antara laki-laki dan perempuan. Artinya, laki-laki dan perempuan boleh menggunakan ruangan manapun.

Gender perempuan juga lebih dominan dari pada gender laki-laki dalam hal pemanfaatan ruang-ruang pada rumah. Dan rumah tinggal compound saat ini memiliki bangunan inti yang sama. Pola compound merupakan pola kluster yang unik, dalam satu lingkungan yang dibatasi pagar dinding yang tinggi atau sering disebut dengan pagar bumi, di dalamnya terdapat beberapa rumah tinggal. Biasanya dalam satu compound masih dalam satu kekerabatan atau satu kinship.

Pola penataan ruang zaman sekarang memberikan dampak pada perbedaan gender tersebut, karena di rumah perempuan merasa menjadi raja sebab segala yang berkaitan dengan kebersihan dan perawatan rumah ada pada wewenang perempuan. Sementara laki-laki bertugas jika ada kerusakan dan melakukan perbaikan.

Penelitian ini memiliki cara yang strategis untuk menciptakan teori gender berdasarkan pola penataan ruang rumah, yakni melalui penelitian rumah compound KG. Hasil penelitian ini diharapkan bisa dijadikan modal untuk melakukan studi yang sama terhadap kajian gender berdasarkan dari keilmuan interior. Melihat betapa banyaknya persoalan gender yang masih butuh 
perhatian oleh insan akademisi untuk melakukan pengkajian dan penelitian. Harapannya akan muncul peneliti muda untuk melanjutkan semangat para pendahulu tersebut berdasarkan konsistensi yang selalu diakrapinya. Sehingga penelitian pola penataan ruang rumah compound KG dalam perspektif gender memiliki tujuan positif untuk mendorong penelitian sejenis dengan objek gender yang ada di Indonesia.

\section{DAFTAR PUSTAKA}

Abdullah, Irwan (ed.). 2006. Sangkan Paran Gender. Yogyakarta: Pustaka Pelajar.

Ahmed, Leila, 2000. Wanita Dan Gender Dalam Islam, Akar-akar Historis Perdebatan Modern, Penerbit Lentera; Jakarta.

Amiseno, Wondo, 1986, Kotagede between Two Gates, Department of Architecture, Engineering Faculty Gadjah Mada University, Yogyakarta.

Arya, Ronald. 1990. Ciri-ciri Budaya di Balik Tabir Keagungan Rumah Jawa. Yogyakarta: Universitas Atma Jaya.

Arikunto, Suharsimi. 2010. Prosedur Penelitian Suatu Pendekatan Praktik. Jakarta: Rineka Cipta.

Bandel, Katrin, 2016. Kajian Gender Dalam Konteks Pascakolonial. Sanata Dharma University Press; Yogyakarta.

2015. Bahan Bacaan Kuliah Kajian Gender. Program Magister Ilmu Religi dan Budaya, Universitas Sanata Dharma Yogyakarta.

Chabot, H. Th. 1996. Kinship Status Gender In Sout Celebes. KITLV Press; Leiden.

Ching, Francis D.K. 1996. Ilustrasi Desain Interior, terjemahan Paul Hanoto Adji, 1996. Erlangga, Jakarta.

Dakung, Drs. Sugiarto. 1987, Arsitektur Tradisional Daerah Istimewa Yogyakarta, Departemen Pendidikan dan Kebudayaan, Yogyakarta.

Fakih, Mansour. 2001. Analisis Gender \& Transformasi Sosial. Yogyakarta: Pustaka Pelajar.

Herusatoto, Budiono, 1983. Simbolisme Budaya Jawa, Penerbit PT. Hanindata; Yogyakarta.

Illich, Ivan, 1998. Matinya Gender. Pustaka Pelajar; Yogyakarta.

Indartoro, L, 1992, Rumah Tinggal di Kotagede, Tinjauan Tipologi dan Morphologi, Tesis Pascasarjana, Program Studi Teknik Arsitektur UGM, Yogyakarta.

Iswati, Triyuni, 2001, Perubahan Denah Rumah Tinggal di Kampung Dalem Kotagede, Tesis, Pascasarjana, Jurusan Teknik Arsitektur UGM, Yogyakarta.

Koentjaraningrat, 1984, Kebudayaan Jawa, Jakarta, Balai Pustaka.

1987, (ed), Metode Metode Penelitian Masyarakat, Jakarta, PT.Gramedia.

Moleong, M. 2007. Metodologi Penelitian Kualitatif. Bandung: PT Remaja Rosdakarya.

Mose, Julia Cleves, 2003. Gender \& Pembangunan. Yogyakarta: Pustaka Pelajar.

Muhadjir, N. 1989. Metodologi Penelitian Kualitatif. Yogyakarta: Rake Sarisin.

Muqoffa, Mohamad. 2005. "Rumah Jawa dalam Dinamika Peruangan sebagai Dampak Hubungan Gender Kasus: Komunitas Kampung Laweyan Surakarta”.Disertasi. Institut Teknologi Sepuluh November.

Muthali'in, Ahmad, 2001. Bias Gender Dalam Pendidikan. Surakarta: Muhammadiyah University Press.

Nasution, S. Metode Penelitian Naturalistik Kualitatif. Bandung: Tarsito. 1988.

Rachmatullah, Asep. 2010, Falsafah Hidup Jawa. Yogyakarta: Logung Pustaka.

Ratna, Prof.Dr.Nyoman Kutha, SU. 2010. Metodologi Penelitian; Kajian Budaya dan Ilmu Sosial Humanoria pada Umumnya, Pustaka Pelajar, Yogyakarta.

Rohidi, Tjejep Rohendi. Metode Penelitian Seni. Semarang: Cipta Prima Nusantara, 2011.

Roqib, Moh. 2007. Harmoni dalam Budaya Jawa. Purwokerto: STAIN Purwokerto Press.

Suryo, Djoko, dkk., 1985, Gaya Hidup Masyarakat Jawa Di Pedesaan : Pola Kehidupan Sosial Ekonomi dan Budaya, Departemen Pendidikan dan Kebudayaan Direktorat Jenderal Kebudayaan. 